\title{
Corn-Soybean Rotation Systems in the Mississippi Delta: Implications on Mycotoxin Contamination and Soil Populations of Aspergillus flavus
}

\author{
Hamed K. Abbas, ${ }^{1}$ Nacer Bellaloui, ${ }^{2}$ Robert M. Zablotowicz, ${ }^{3}$ \\ H. Arnold Bruns, ${ }^{3}$ and Anne M. Gillen ${ }^{2}$ \\ ${ }^{1}$ Biological Control of Pests Research Unit, Agricultural Research Service, US Department of Agriculture, Stoneville, MS 38776, USA \\ ${ }^{2}$ Crop Genetics Research Unit, Agricultural Research Service, US Department of Agriculture, Stoneville, MS 38776, USA \\ ${ }^{3}$ Crop Production Systems Research Unit, Agricultural Research Service, US Department of Agriculture, Stoneville, MS 38776, USA
}

Correspondence should be addressed to Hamed K. Abbas, hamed.abbas@ars.usda.gov

Received 23 December 2011; Revised 29 February 2012; Accepted 19 June 2012

Academic Editor: Kent Burkey

Copyright ( $\odot 2012$ Hamed K. Abbas et al. This is an open access article distributed under the Creative Commons Attribution License, which permits unrestricted use, distribution, and reproduction in any medium, provided the original work is properly cited.

\begin{abstract}
The effect of corn-soybean rotation on mycotoxin contamination in corn (Zea mays L.) and soybean (Glycine max L. Merrill.) grains has not been fully evaluated. Therefore, this research investigated the effect of corn-soybean rotation on aflatoxin and fumonisin contamination in respective grains. The results showed that aflatoxin levels in soybean averaged $2.3,<0.5,0.6$, and $6.8 \mathrm{ng} / \mathrm{g}$ in 2005, 2006, 2007, and 2008, while corn aflatoxin levels were 16.7, 37.1, 2.4, and $54.8 \mathrm{ng} / \mathrm{g}$, respectively. Aspergillus flavus colonization was significantly greater $(P \leq 0.05)$ in corn $(\log 1.9,2.9$, and $4.0 \mathrm{cfu} / \mathrm{g})$ compared to soybean $(<1.3,2.6$, and $2.7 \mathrm{cfu} / \mathrm{g})$ in 2005, 2007, and 2008, respectively. Aflatoxigenic A. flavus isolates were more frequent in corn than in soybean in all four years. Higher fumonisin levels were found in corn $(0.2$ to $3.6 \mu \mathrm{g} / \mathrm{g})$ than in soybean $(<0.2 \mu \mathrm{g} / \mathrm{g})$. Rotating soybean with corn reduces the potential for aflatoxin contamination in corn by reducing $A$. flavus propagules in soil and grain and reducing aflatoxigenic $A$. flavus colonization. These results demonstrated that soybean grain is less susceptible to aflatoxin contamination compared to corn due to a lower level of colonization by $A$. flavus with a greater occurrence of non-aflatoxigenic isolates.
\end{abstract}

\section{Introduction}

Corn (Zea mays L.) and soybean (Glycine max L. Merrill.) crop rotation systems are a well-established practice in the North Central and Mid Atlantic regions of the United States. Various rotational systems using these two crops have been developed, beginning in the early 1950's when soybean became an established oil seed crop for these two regions. The benefits of corn-soybean rotation have been reported in the past 20 years [1]. It was shown that corn yields increased following at least one year of soybean production on most of all soils compared with yields from continuous corn production. These increases were associated with the disruption of diseases, insects, weeds' lifecycles through the changing of crop species, and the required management. In some cases, residual $\mathrm{N}$ fixed by the soybean is utilized by the following corn crop, resulting in higher corn yield.
In the Mid-South United States, as with other humid subtropical regions of the world, corn can be infected with Aspergillus flavus prior to harvest, resulting in grain contamination with aflatoxin, a potent carcinogen at very low levels. Aflatoxin is regulated by the United States Food and Drug Administration (FDA) with a maximum of $20 \mathrm{ng} / \mathrm{g}$ for corn contamination entering interstate commerce. Levels $10 \mathrm{ng} / \mathrm{g}$ or less are imposed by various countries [2]. A major outbreak in 1998 of aflatoxin contamination in the southern USA was estimated to have resulted in $\$ 85$ million to $\$ 100$ million in losses in Arkansas, Louisiana, Mississippi, and Texas [3]. In addition to A. flavus infection, corn kernels are susceptible to other toxigenic fungi such as Fusarium verticillioides (syn. F. moniliforme) $[4,5]$ and can produce fumonisins [6-8]. This group of mycotoxins is considered one of the most common toxins in corn and their products (CAST [9]). Fumonisins cause disease in livestock such as 
equine leukoencephalomalacia and pulmonary edema in swine. Fumonisins are also associated with esophageal cancer in humans and are proven tumor promotors in rats (CAST [9]; [10]; NTP [11]). Fumonisins are regulated by the FDA with $2-4 \mu \mathrm{g} / \mathrm{g}$ maximum levels allowed in corn, depending on use [2].

Research on management practices such as harvest dates, fertility, planting dates, hybrids, and their influence on aflatoxin and fumonisin contamination in corn have been previously conducted in the Mid South [12-14]. Bruns and Abbas have shown that higher grain yields coincided with reduced levels of aflatoxin and fumonisin contaminations. High temperatures and drought are well documented to impact aflatoxin and fumonisin levels in corn [7]. Aflatoxins and fumonisin are often coexistent in corn and conducive environment, facilitating infestation $[6,7,15,16]$. Soybean is generally considered a poor substrate for aflatoxin production and not subject to contamination [17]. Since there are no commercial corn or soybean mycotoxin-resistant cultivars available, management practices could be an alternative to reduce toxin levels of these two pathogens in corn. Therefore, the objectives of this research were to examine the effects of various corn-soybean rotations on A. flavus colonies, and aflatoxin and fumonisin contamination in corn and soybean grains. The results will be useful for managing mycotoxin contamination and improving economic return for growers.

\section{Materials and Methods}

The research was conducted from 2005 through 2008 on a Dundee silty clay (fine-silty, mixed, thermic Aeric Ochraqualfs) at the Mississippi State University's Delta Branch Experiment Station at Stoneville, MS. The experimental design was a randomized complete block replicated four times. Individual experimental units consisted of one of the following eight crop rotation regimes: (1) continuous corn (C-C-C-C), (2) continuous soybean (S-S-S-S), (3) corn-soybean (C-S), (4) soybean-corn (S-C), (5) corncorn-soybean-soybean (C-C-S-S), (6) corn-corn-soybeancorn (C-C-S-C), (7) soybean-soybean-corn-corn (S-S-CC), and (8) soybean-soybean-corn-soybean (S-S-C-S). These regimes were assigned to an experimental unit at the initiation of the experiment and remained in place throughout the study. Individual experimental units consisted of eight 9meter rows, space $76 \mathrm{~cm}$ apart. The crop planted on the site prior to initiation of the experiment was soybean.

Land preparation began in late winter each year with $30 \mathrm{~cm}$ ridges being formed and then harrowed just prior to planting. Soybean and corn cultivars were used, depending on their availability in the market. The soybean cultivar DBK46-51 was planted in all years, while the corn hybrid Dekalb DKC42-70 was used in 2005 and 2006, and DKC6019 was used in 2007 and 2008. Planting dates for both corn and soybean were 7 Apr. 2005, 12 Apr. 2006, 11 Apr. 2007, and 14 Apr. 2008. The experiment was furrow irrigated and scheduled so that approximately $25 \mathrm{~mm}$ of water was applied every 10 days beginning at anthesis or 10 days after the last rainfall event of $25 \mathrm{~mm}$ or more until the corn reached growth stage R6 (physiological maturity) as defined by Ritchie et al. [18].

Aspergillus flavus populations were determined by collecting surface soil samples $(0$ to $5 \mathrm{~cm})$ using a sterile scoop. Each sample was a composite of eight samples taken from the two center rows midway in the plots in the spring prior to planting and fall within a week of harvest from 2006 to 2008. Samples were passed through a $2 \mathrm{~mm}$ sieve and stored at $4^{\circ} \mathrm{C}$. Soil moisture was determined on a $50 \mathrm{~g}$ subsample monitoring moisture loss after $48 \mathrm{~h}$ at $60^{\circ} \mathrm{C}$.

Estimates of $A$. flavus propagule density in soil (colony forming units) were determined by diluting $2.5 \mathrm{~g}$ of soil in $10 \mathrm{~mL}$ of $0.2 \%$ water agar, vortexed, plating $200 \mu \mathrm{L}$ of the soil suspension on 4 MDRB (modified dichloronitroaniline rose Bengal agar), and incubated for 3 days at $37^{\circ} \mathrm{C}$ [19]. Colonies of $A$. flavus were counted and ten colonies per replication were picked at random, transferred to $\beta$-cyclodextrin $(0.3 \%)$ potato dextrose agar $(\beta-\mathrm{cPDA})$, and incubated in dark at $28^{\circ} \mathrm{C}$ for 3 days. Colonies were evaluated for fluorescence and toxigenicity based on fluorescent colonies [20]. Colony forming units of $A$. flavus on ground corn and soybeans were determined using a serial dilution method [21]. Grown grain $(10 \mathrm{~g})$ was suspended in $0.2 \%$ water agar and shaken for $30 \mathrm{~min}$ on a reciprocal shaker. The samples were serially diluted as needed and $200 \mu \mathrm{L}$ was spread on MDRB plates, 4 per dilution.

Assessment of A. flavus contaminated corn and soybean seed was also conducted each year as described in Abbas et al. [21]. For each sample, 10 surface sterilized seeds were plated on five MDRB plates per plot. The number of positive colonies was counted after three days at $28^{\circ} \mathrm{C}$ to determine the percentage of infected seed. Thereafter, any putative A. flavus colonies were transferred to $0.3 \% \beta$-cPDA and evaluated as previously mentioned.

Aflatoxin and fumonisin determinations were made using an enzyme-linked immunosorbent assay (ELISA) analysis of aflatoxin and fumonisin per included instructions in a commercially available ELISA kit (Neogen Corporation, Lansing, MI; [6]). Aflatoxin analysis by ELISA mainly was conducted to quantify aflatoxin levels prior to HPLC analysis, while values determined by ELISA for fumonisin were used directly. Briefly, sample cleanup was carried out with a minor modification and the limit of detection was $0.1 \mathrm{ng} / \mathrm{g}$, using method of Abbas et al. [7].

Analysis of variance across years was conducted using Proc Mixed in SAS (SAS [22]) using block, rotation, year, and year $\mathrm{x}$ rotation as fixed effects and the repeated option was used. Since years were significant, the data was analyzed by year using Proc Mixed in SAS with block, crop, and rotation within crop as fixed effects. Data obtained from mycotoxin concentrations and other seed quality parameters in corn and soybean were analyzed using PROC GLM (SAS [22]) and means comparisons were made using Fisher's LSD.

\section{Results}

Asperillgus propagule densities in soil samples collected over the three years from the fall of 2006 to the fall of 2008 are 
TABLE 1: Effect of previous crop on Aspergillus flavus soil propagules and frequency of toxigenic isolates. ${ }^{1}$

\begin{tabular}{|c|c|c|c|c|c|c|}
\hline \multirow[t]{2}{*}{ Sample } & \multicolumn{2}{|c|}{ Colony forming units $\log (10) / g$ soi } & \multicolumn{4}{|c|}{ Aflatoxigenic isolates \% } \\
\hline & Corn & Soybean & LSD 0.05 & Corn & Soybean & LSD 0.05 \\
\hline Fall 2006 & $2.16 \mathrm{a}$ & $2.32 \mathrm{a}$ & 0.17 & $57.1 \mathrm{a}$ & $64.2 \mathrm{a}$ & 11.4 \\
\hline Spring 2007 & $3.22 \mathrm{a}$ & $3.20 \mathrm{a}$ & 0.09 & $58.9 \mathrm{a}$ & $54.9 \mathrm{a}$ & 6.2 \\
\hline Fall 2007 & $2.40 \mathrm{a}$ & $2.35 \mathrm{a}$ & 0.19 & $47.1 \mathrm{a}$ & $42.1 \mathrm{a}$ & 10.3 \\
\hline Spring 2008 & $2.85 \mathrm{a}$ & $2.71 \mathrm{~b}$ & 0.10 & $55.1 \mathrm{a}$ & $50.9 \mathrm{a}$ & 9.4 \\
\hline Fall 2008 & $2.39 \mathrm{a}$ & $2.17 \mathrm{~b}$ & 0.21 & $57.4 \mathrm{a}$ & $60.3 \mathrm{a}$ & 13.1 \\
\hline
\end{tabular}

${ }^{1}$ Means within a row in each year for each variable followed by the same letter are not significantly different at the $5 \%$ level.

TABLE 2: Analysis of variance and probability values of seed quality parameters as affected by block, rotation, year, and their interactions ${ }^{1}$.

\begin{tabular}{|c|c|c|c|c|c|c|}
\hline Source & $\begin{array}{c}\text { Aspergillus flavus propagules } \\
\text { log transformed }\end{array}$ & $\begin{array}{c}\text { Aflatoxigenic } \\
\text { propagules (\%) }\end{array}$ & $\begin{array}{l}\text { Aspergillus- } \\
\text { infected } \\
\text { seed }\end{array}$ & $\begin{array}{c}\text { Aflatoxin } \\
\text { concentration }\end{array}$ & $\begin{array}{l}\text { Fumonisin } \\
\text { concentration }\end{array}$ & $\begin{array}{l}\text { Aflatoxin concentration } \\
\text { log transformed }\end{array}$ \\
\hline Block & 0.079 & 0.59 & 0.22 & 0.79 & 0.37 & 0.47 \\
\hline Rotation & $* *$ & 0.061 & $* * *$ & 0.31 & $* * *$ & 0.063 \\
\hline Year & $* * *$ & $* * *$ & $* * *$ & $*$ & $* * *$ & $* * *$ \\
\hline $\begin{array}{l}\text { Year } \times \\
\text { Rotation }\end{array}$ & $* * *$ & $* *$ & $* * *$ & 0.31 & $* * *$ & 0.18 \\
\hline
\end{tabular}

${ }^{1}$ Levels of significance were as follows:, ${ }^{*} P \leq 0.05 ;{ }^{* *} P \leq 0.01 ; * * P \leq 0.001$.

summarized in Table 1. Many of the soil samples $(>50 \%)$ processed in 2005 were below the detection limit $(<\log$ 1.2 CFU/g soil), therefore the number of plates utilized per sample were increased from 2 to 5 . In subsequent years, there was no consistent effect of any particular rotation sequence on A. flavus propagule densities or frequency of aflatoxigenic isolates, thus soil data is summarized based on previous crop for the spring counts and the recently harvested crop for fall counts. Soil populations were between two- to tenfold higher in the spring preplant sampling than the fall postharvest sampling. By the fourth year of the study (2008), soils collected from plots planted to corn in previous years were significantly greater compared to soybean plots. However, similar occurrence of aflatoxigenic $A$. flavus was observed in all cropping sequences, ranging from 47 to $60 \%$ of the isolates producing aflatoxin, with no effect of crop. All the isolates of putative Aspergillus were identified as A. flavus according to the identification index reported by [23].

Analysis of variance showed that year was significant for all variables, and year and rotation were main sources of variability for all variables. Since the interaction between year and rotation was significant, analysis by year was conducted (Table 2). The differences between crops could not be examined in the across-years analysis because crop is part of rotation. The ANOVA by year indicated that the type of crop in rotation that year had a significant influence on these variables and that the rotation within each crop was not significant except for fumonisin concentration in 2005 and 2008 (Table 3). Block was not significant except for aflatoxin concentration log transformed in 2005 and Apergillus propagule in 2007.

Seed quality assessment based on Aspergillus propagule density, level of Aspergillus-contaminated seed, frequency of toxigenic A. flavus isolates, and aflatoxin (ng/g) and fumonisin $(\mu \mathrm{g} / \mathrm{g})$ levels in corn and soybean grain, collected over the four years study, are summarized in Table 4. Again, all the isolates of putative Aspergillus selected for assessment of toxin production were identified as A. flavus according to the identification index of [23]. No consistent effect of single cropping sequence on seed quality parameters was shown (Table 3), thus analysis compared data from corn versus soybean. In the initial year of the study, the lowest occurrence of Aspergillus contamination was log 1.93 and $1.30 \mathrm{CFU} / \mathrm{g}$ seed in both corn and soybean, respectively. In all years except 2006, significantly higher propagules of $A$. flavus were observed in corn than in soybean grain, with levels of A. flavus exceeding 1000 propagules/g in over half of the corn and one-third of the soybean samples. Consistent low propagule densities and lower level of Aspergillus contaminated seed were found in 2005. However, the percentage of A. flavus contaminated seed was significantly greater in corn compared to soybean in 2005,2006 , and 2008. Likewise, the occurrence of aflatoxigenic isolates was significantly greater in corn grain compared to soybean in the same three years. Nevertheless, relatively high levels of colonization of soybean seed by $A$. flavus [log (10) 2.63 to 3.33] were observed in soybean in 2006, 2007, and 2008. Aflatoxin levels were significantly higher levels in corn than soybean in two of the four years (2005 and 2008), while fumonisin levels were significantly greater in corn compared to soybean in all years except 2007. As observed in most field studies, a wide range of mycotoxin contamination was found among samples with plot-to-plot variability within particular treatments, thus frequency histograms are presented to indicate relative patterns (Figures 1 and 2). Overall, 28 of 64 corn samples had aflatoxin levels exceeding $10 \mathrm{ng} / \mathrm{g}$, while only four of 64 soybean samples did (Figures 1(a) and 1(b)), while 17 of 64 corn samples had fumonisin levels exceeding $1 \mu \mathrm{g} / \mathrm{g}$ 


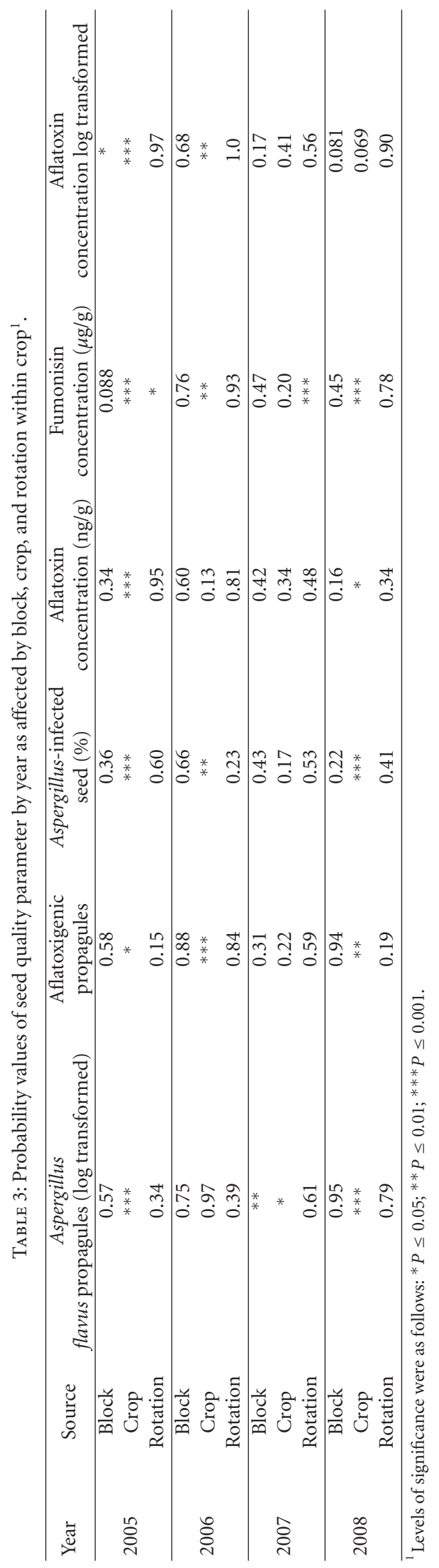


TABLE 4: Seed quality parameters relating to mycotoxin contamination in corn and soybean averaged among rotations 2005 to $2008 .{ }^{1}$

\begin{tabular}{|c|c|c|c|c|c|c|}
\hline Year & Crop & $\begin{array}{c}\text { Aspergillus propagules } \\
\text { Log (10) CFU/g }\end{array}$ & $\begin{array}{c}\text { Aspergillus infected } \\
\text { seed \% } \\
\end{array}$ & Toxigenic isolates & $\begin{array}{c}\text { Aflatoxin } \\
(\mathrm{ng} / \mathrm{g})\end{array}$ & $\begin{array}{c}\text { Fumonisin } \\
(\mu \mathrm{g} / \mathrm{g})\end{array}$ \\
\hline \multirow{3}{*}{2005} & Corn & $1.93 \mathrm{a}$ & $33.6 \mathrm{a}$ & $28.5 \mathrm{a}$ & $16.7 \mathrm{a}$ & $3.6 \mathrm{a}$ \\
\hline & Soybean & $1.30 \mathrm{~b}$ & $7.0 \mathrm{~b}$ & $15.9 \mathrm{~b}$ & $2.3 \mathrm{~b}$ & $0.1 \mathrm{~b}$ \\
\hline & LSD & 0.30 & 10.0 & 12.1 & 4.2 & 1.0 \\
\hline \multirow{3}{*}{2006} & Corn & $3.33 \mathrm{a}$ & $78 \mathrm{a}$ & $77 \mathrm{a}$ & $37.1 \mathrm{a}$ & $0.9 \mathrm{a}$ \\
\hline & Soybean & $3.33 \mathrm{a}$ & $66 \mathrm{~b}$ & $7 \mathrm{~b}$ & $0.1 \mathrm{~b}$ & $0.2 \mathrm{~b}$ \\
\hline & LSD & NS & 8 & 12 & 1.2 & 0.3 \\
\hline \multirow{3}{*}{2007} & Corn & $2.93 \mathrm{a}$ & $44 \mathrm{a}$ & $17 \mathrm{a}$ & $2.4 \mathrm{a}$ & $0.2 \mathrm{a}$ \\
\hline & Soybean & $2.63 \mathrm{~b}$ & $30 \mathrm{a}$ & $10 \mathrm{a}$ & $0.6 \mathrm{a}$ & $0.1 \mathrm{a}$ \\
\hline & LSD & 0.22 & NS & NS & NS & NS \\
\hline \multirow{3}{*}{2008} & Corn & $3.99 \mathrm{a}$ & $93 \mathrm{a}$ & $46 \mathrm{a}$ & $54.8 \mathrm{a}$ & $3.5 \mathrm{a}$ \\
\hline & Soybean & $2.72 \mathrm{~b}$ & $36 \mathrm{~b}$ & $31 \mathrm{~b}$ & $6.8 \mathrm{~b}$ & $0.2 \mathrm{~b}$ \\
\hline & LSD & 0.25 & 12 & 10 & 2.1 & 1.0 \\
\hline
\end{tabular}

${ }^{1}$ Means within a column in each year for each variable followed by the same letter are not significantly different at the $5 \%$ level.

(Figures 2(a) and 2(b)). No soybean samples contained greater than $1 \mu \mathrm{g} / \mathrm{g}$ fumonisin. The wide range of toxin levels observed in these plots is consistent with the range of variability associated for spatial effects described in other studies [21]. These observations indicate the relative increased susceptibility of corn compared to soybean for contamination by $A$. flavus and subsequent mycotoxin contamination. Although soybean is subject to infection by several species of Fusarium, apparently it is relatively resistant to the seed contaminating fumonisin producing Fusaria.

\section{Discussion}

In this study we did not observe any significant effect of previous crop or rotation system on soil populations of A. flavus until the fourth year of the experiment. These field plots were under conventional tillage management, and subsequent crop residues were distributed in the upper $20 \mathrm{~cm}$ of soil. Zablotowicz et al. [19] also reported that levels of A. flavus are higher in soils with high amounts of organic matter, especially with no tillage; however, no consistent effect of cropping history was observed. In an intensive sampling of a growers field under no-tillage management, Abbas et al. [21] also found that A. flavus population were higher after corn than either after cotton or wheat in a threeyear study in field located in Mississippi Delta. Recent studies by Jaime-Garcia and Coty [24] indicated that when corn is the previous crop, higher soil populations of $A$. flavus were observed.

In this current study we observed that a significant amount of contamination of soybean seed by A. flavus was found, although less than $30 \%$ of soybean isolates were aflatoxin producing. It was reported that moldy soybean does not contain a large amounts of aflatoxin under wet conditions. The most consistently higher levels of aflatoxin contamination in both corn and soybean was in 2008 when the maximum temperature in all of July exceeded $32^{\circ} \mathrm{C}$ with 4 days greater than $37.5^{\circ} \mathrm{C}$. In addition, rainfall in June and July was lower than any of the four years of the study, favoring aflatoxin accumulation. The wet conditions cause mold on the soybeans $[25,26]$. The level of aflatoxins in 2007 was very low in both corn and soybean due to the weather conditions (rainy and cool temperatures). This was in agreement with what reported before by Abbas and Shier [27] and Bruns and Abbas [28]. Soybean seed and vegetative matter typically have greater than $5 \%$ nitrogen content [29], while corn is typically less than 3\% [30]. The relative abundance of nitrogen compared to carbon may also limit aflatoxin production in soybean. Payne and Brown [31] reported that the amino acid alanine, aspartate, glutamate, and glutamine increase the levels of aflatoxins in culture. In addition, soybean is known to produce volatile compounds which have an adverse effect on Aspergillus growth, population, and aflatoxin biosynthesis [32].

Analysis of fumonisin contamination indicated that over $25 \%$ of corn, while no soybean samples, contained greater than $1 \mu \mathrm{g} / \mathrm{g}$ fumonisin. Abbas and Bosch [25] reported Fusarium species disease in soybeans was high after cool and wet conditions with no or minimal detection of mycotoxins in Minnesota soybean field. Castellá et al. [33] reported the presence of fumonisin and Fusarium species in soybean in Spain. Acuña et al. [34] also found that Fusarium species isolated from selected field samples in Colombian, including soybean, can produce fumonisin. It is well documented that Fusarium species cause wilt and root diseases in soybean [35]. In this intensively monitored four-year field study, we have discovered that soybeans are less susceptible to aflatoxin contamination compared to corn because of their greater colonization by nonaflatoxigenic isolates and a greater host specificity for aflatoxigenic $A$. flavus isolates in corn. A soybean/corn rotation aids in the reduction of $A$. flavus propagules in soil and subsequent colonization of corn grain, thus reducing potential for aflatoxin contamination in corn. Likewise rotating with soybean reduces the potential for fumonisin contamination in corn. 


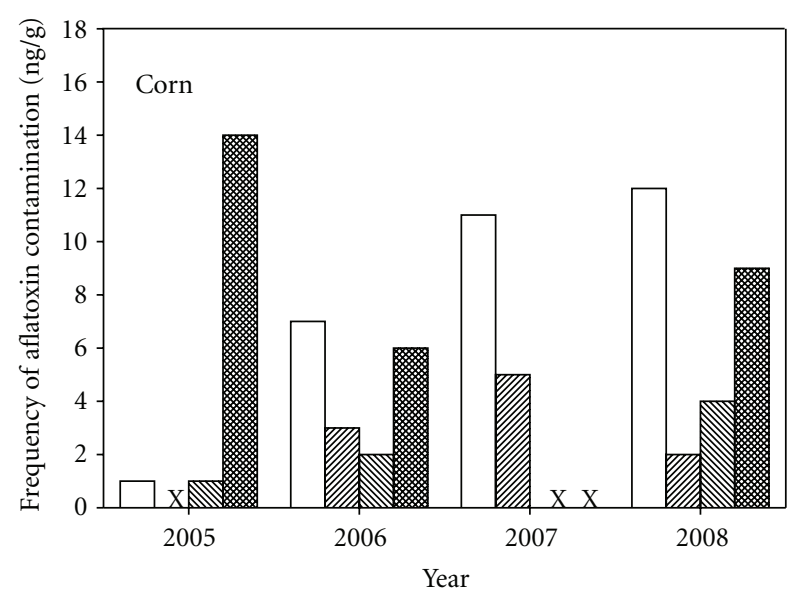

(a)

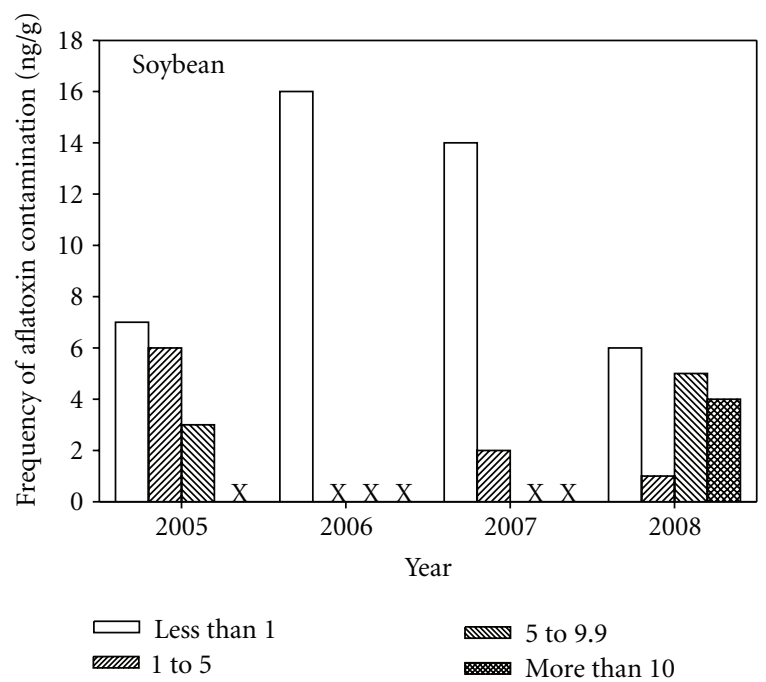

(b)

FIGURE 1: Frequency of aflatoxin contamination levels in corn (a) and soybean (b) in four years of field trials, each year 16 plots were planted to corn and soybean. $\mathrm{X}$ in the graph indicates zero frequency.

\section{Acknowledgments}

The authors appreciate the technical assistance of Ms. Bobbie J. Johnson. Also, they thank Gary Shelton, Will Marlow, Robert L. Paris, and Rodrick Patterson for establishing field tests. The mention of trade names or commercial products is solely for the purpose of providing specific information and does not imply recommendation or endorsement by the US Department of Agriculture.

\section{References}

[1] B. Erickson, "Corn/soybean rotation literature summary," 2008, http://www.agecon.purdue.edu/pdf/Crop_Rotation_Lit_ Review.pdf.

[2] H. P. van Egmond, R. C. Schothorst, and M. A. Jonker, "Regulations relating to mycotoxins in food : perspectives in

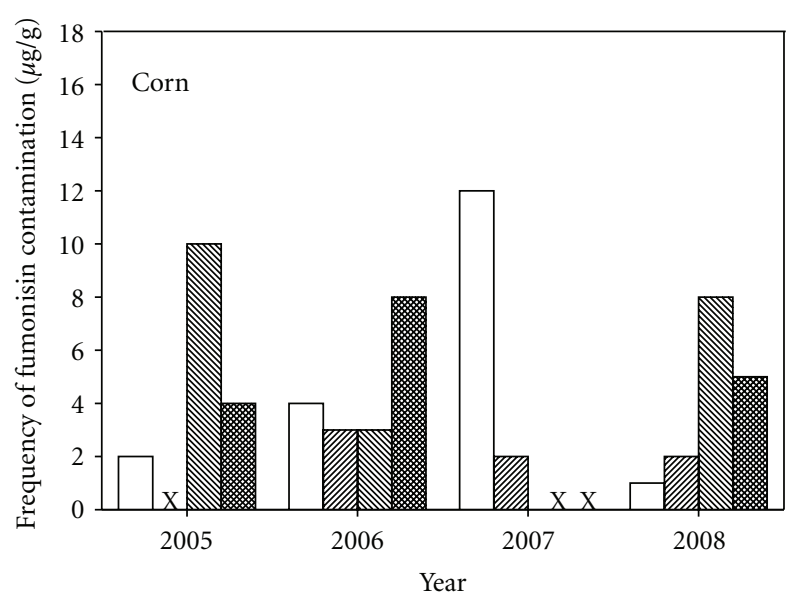

(a)

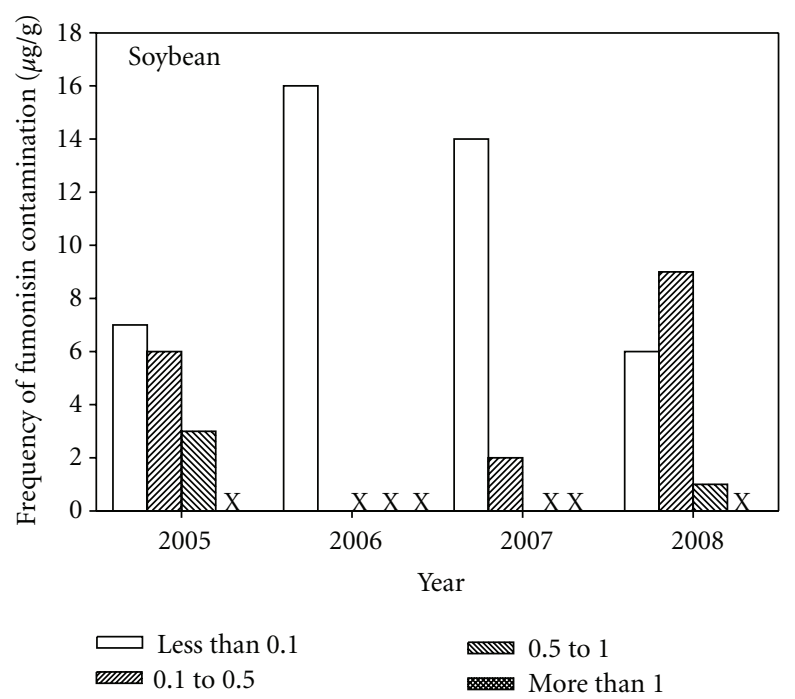

(b)

Figure 2: Frequency of fumonisin contamination levels in corn (a) and soybean (b) in four years of field trials, each year 16 plots were planted to corn and soybean. $\mathrm{X}$ in the graph indicates zero frequency.

a global and European context," Analytical and Bioanalytical Chemistry, vol. 389, no. 1, pp. 147-157, 2007.

[3] J. Robens and K. Cardwell, "The costs of mycotoxin management to the USA: management of aflatoxins in the United States," Journal of Toxicology, vol. 22, no. 2-3, pp. 139-152, 2003.

[4] K. F. Cardwell, J. G. Kling, B. Maziya-Dixon, and N. A. Bosque-Pérez, "Interactions between Fusarium verticillioides, Aspergillus flavus, and insect infestation in four maize genotypes in lowland Africa," Phytopathology, vol. 90, no. 3, pp. 276-284, 2000.

[5] N. Zummo and G. E. Scott, "Interaction of Fusarium moniliforme and Aspergillus flavus on kernel infection and aflatoxin contamination in maize ears," Plant Disease, vol. 76, pp. 771$773,1992$.

[6] H. K. Abbas, W. P. Williams, G. L. Windham, H. C. Pringle Jr., W. Xie, and W. T. Shier, "Aflatoxin and fumonisin 
contamination of commercial corn (Zea mays) hybrids in Mississippi," Journal of Agricultural and Food Chemistry, vol. 50, no. 18, pp. 5246-5254, 2002.

[7] H. K. Abbas, W. T. Shier, and R. D. Cartwright, "Effet of temperature, rainfall and planting date on aflatoxin and fumonisin contamination in commercial Bt and non-Bt corn hybrids in Arkansas," Phytoprotection, vol. 88, no. 2, pp. 41-50, 2007.

[8] J. P. Rheeder, W. F. O. Marasas, and H. F. Vismer, "Production of fumonisin analogs by Fusarium species," Applied and Environmental Microbiology, vol. 68, no. 5, pp. 2101-2105, 2002.

[9] CAST (Council for Agriculture Science and Technology), "Mycotoxins risks in plant, animal, and human systems," IA Task Force Report 139, CAST, Ames, 2003.

[10] T. S. Dowling, "Fumonisin and its toxic effects," Cereal Foods World, vol. 42, no. 1, pp. 13-15, 1997.

[11] NTP (National Toxicology Program), "Toxicology and carcinogenesis studies on fumonisin B1 in F344/N rats and B6CF1 mice (feed studies)," Tech. Rep. 496, U.S. Department of Health and Human Services, National Institutes of Health, Research Triangle Park, NC, USA, 1999, NIH Publication No. 99-3955.

[12] H. A. Bruns and H. K. Abbas, "Effects of harvest date on maize in the humid sub-tropical mid-south USA," Maydica, vol. 49, no. 1, pp. 1-7, 2004.

[13] H. A. Bruns and H. K. Abbas, "Ultra-high plant populations and nitrogen fertility effects on corn in the Mississippi Valley," Agronomy Journal, vol. 97, no. 4, pp. 1136-1140, 2005.

[14] H. A. Bruns and H. K. Abbas, "Planting date effects on Bt and non-Bt corn in the Mid-South USA," Agronomy Journal, vol. 98, no. 1, pp. 100-106, 2006.

[15] W. J. Chamberlain, C. W. Bacon, W. P. Norred, and K. A. Voss, "Levels of fumonisin B1 in corn naturally contaminated with aflatoxins," Food and Chemical Toxicology, vol. 31, no. 12, pp. 995-998, 1993.

[16] J. W. Park, E. K. Kim, D. H. Shon, and Y. B. Kim, "Natural co-occurrence of aflatoxin B1, fumonisin B1 and ochratoxin A in barley and corn foods from Korea," Food Additives and Contaminants, vol. 19, no. 11, pp. 1073-1080, 2002.

[17] O. L. Shotwell, E. E. Vandegraft, and C. W. Hesseltine, "Aflatoxin formation on sixteen soybean varieties," Journal of Association of Official Analytical Chemists International, vol. 61, no. 3, pp. 574-577, 1978.

[18] S. W. Ritchie, J. J. Hanway, and G. O. Benson, How a Corn Plant Develops, Special Report, no. 48, Iowa State University of Science and Technology, Cooperative Extension Service, Ames, Iowa, USA, 1996.

[19] R. M. Zablotowicz, H. K. Abbas, and M. A. Locke, "Population ecology of Aspergillus flavus associated with Mississippi Delta soils," Food Additives and Contaminants, vol. 24, no. 10, pp. 1102-1108, 2007.

[20] H. K. Abbas, R. M. Zablotowicz, M. A. Weaver, B. W. Horn, W. Xie, and W. T. Shier, "Comparison of cultural and analytical methods for determination of aflatoxin production by Mississippi Delta Aspergillus isolates," Canadian Journal of Microbiology, vol. 50, no. 3, pp. 193-199, 2004.

[21] H. K. Abbas, R. M. Zablotowicz, and M. A. Locke, "Spatial variability of Aspergillus flavus soil populations under different crops and corn grain colonization and aflatoxins," Canadian Journal of Botany, vol. 82, no. 12, pp. 1768-1775, 2004.

[22] SAS, SAS, (r) Proprietary Software Release 9. 1, SAS Institute Inc., Cary, NC, USA, 2003.
[23] M. A. Klich, Identication of Common Aspergillus Species, Centralbureau voor Schimmelculyures, Ultrecht, The Netherlands, 2002.

[24] R. Jaime-Garcia and P. J. Cotty, "Crop rotation and soil temperature influence the community structure of Aspergillus flavus in soil," Soil Biology and Biochemistry, vol. 42, no. 10, pp. 1842-1847, 2010.

[25] H. K. Abbas and U. Bosch, "Evaluation of trichothecene and nontrichothecene mycotoxins produced by Fusarium in soybeans," Mycotoxin Research, vol. 6, no. 1, pp. 13-20, 1990.

[26] G. A. Bean, J. A. Schillinger, and W. L. Klarman, "Occurrence of aflatoxins and aflatoxin-producing strains of Aspergillus spp. in soybeans," Applied Microbiology, vol. 24, no. 3, pp. 437439, 1972.

[27] H. K. Abbas and W. T. Shier, "Mycotoxin contamination of agricultural products in the Southern United States and approaches to reducing it from pre-harvest to final food products," in Mycotoxin Prevention and Control in Agriculture, M. Appll, D. Kendra, and M. W. Trucksess, Eds., vol. 1031 of American Chemical Society Symposium Series, pp. 37-58, Oxford University Press, Oxford, UK, 2009.

[28] H. A. Bruns and H. K. Abbas, "Aflatoxin contamination in corn differs among inoculation techniques," Plant Health Progress. In press.

[29] N. Bellaloui, J. R. Smith, A. M. Gillen, and J. D. Ray, "Effects of maturity, genotypic background, and temperature on seed mineral composition in near-Isogenic soybean lines in the early soybean production system," Crop Science, vol. 51, no. 3, pp. 1161-1171, 2011.

[30] K. N. Reddy, N. Bellaloui, and R. M. Zablotowicz, "Glyphosate effect on shikimate, nitrate reductase activity, yield, and seed composition in corn," Journal of Agricultural and Food Chemistry, vol. 58, no. 6, pp. 3646-3650, 2010.

[31] G. A. Payne and M. P. Brown, "Genetics and physiology of aflatoxin biosynthesis," Annual Review of Phytopathology, vol. 36, pp. 329-362, 1998.

[32] T. E. Cleveland, C. H. Carter-Wientjes, A. J. De Lucca, and S. M. Boué, "Effect of soybean volatile compounds on Aspergillus flavus growth and aflatoxin production," Journal of Food Science, vol. 74, no. 2, pp. H83-H87, 2009.

[33] G. Castellá, M. R. Bragulat, and F. J. Cabañes, "Surveillance of fumonisins in maize-based feeds and cereals from Spain," Journal of Agricultural and Food Chemistry, vol. 47, no. 11, pp. 4707-4710, 1999.

[34] A. Acuña, M. C. Lozano, M. C. De García, and G. J. Diaz, "Prevalence of Fusarium species of the Liseola section on selected Colombian animal feedstuffs and their ability to produce fumonisins," Mycopathologia, vol. 160, no. 1, pp. 6366, 2005.

[35] G. L. Hartman, J. B. Sinclair, and J. C. Rupe, "Compendium of soybean diseases," in The American Phytopathological Society, pp. 1-100, APS Press, 4th edition, 1999. 


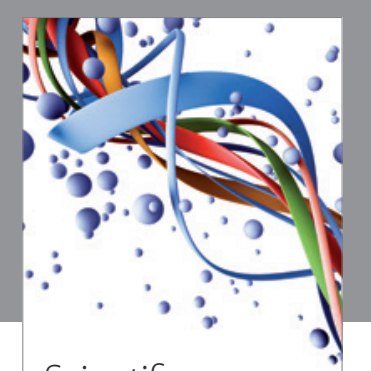

Scientifica
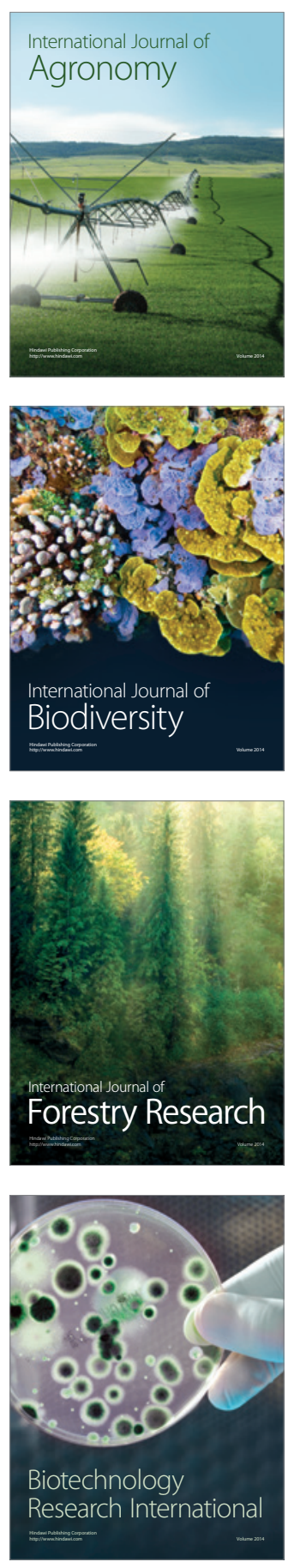
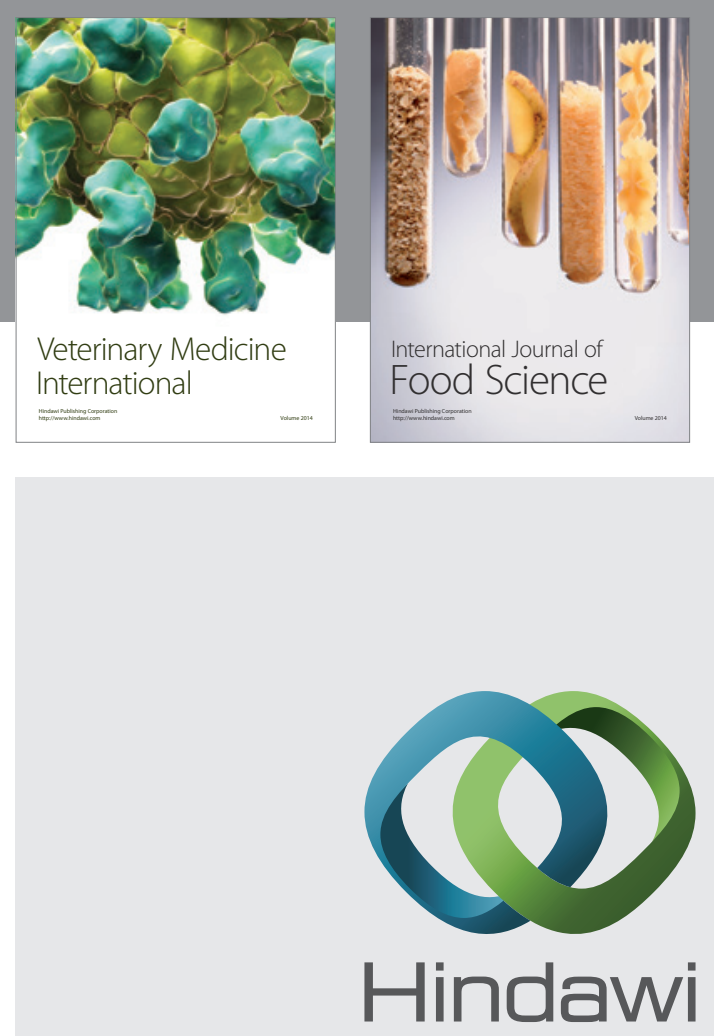

Submit your manuscripts at

http://www.hindawi.com
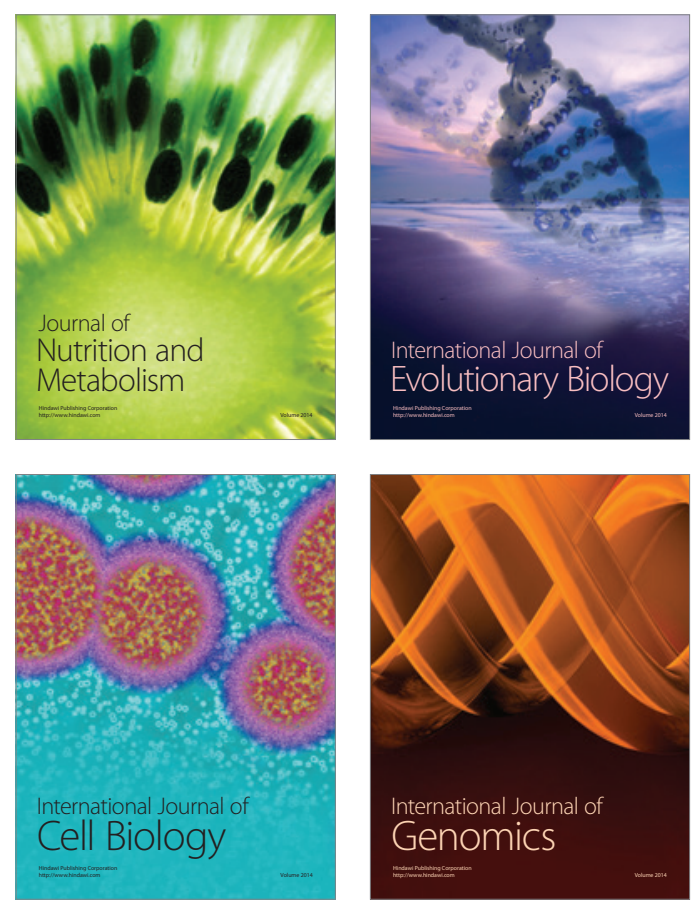
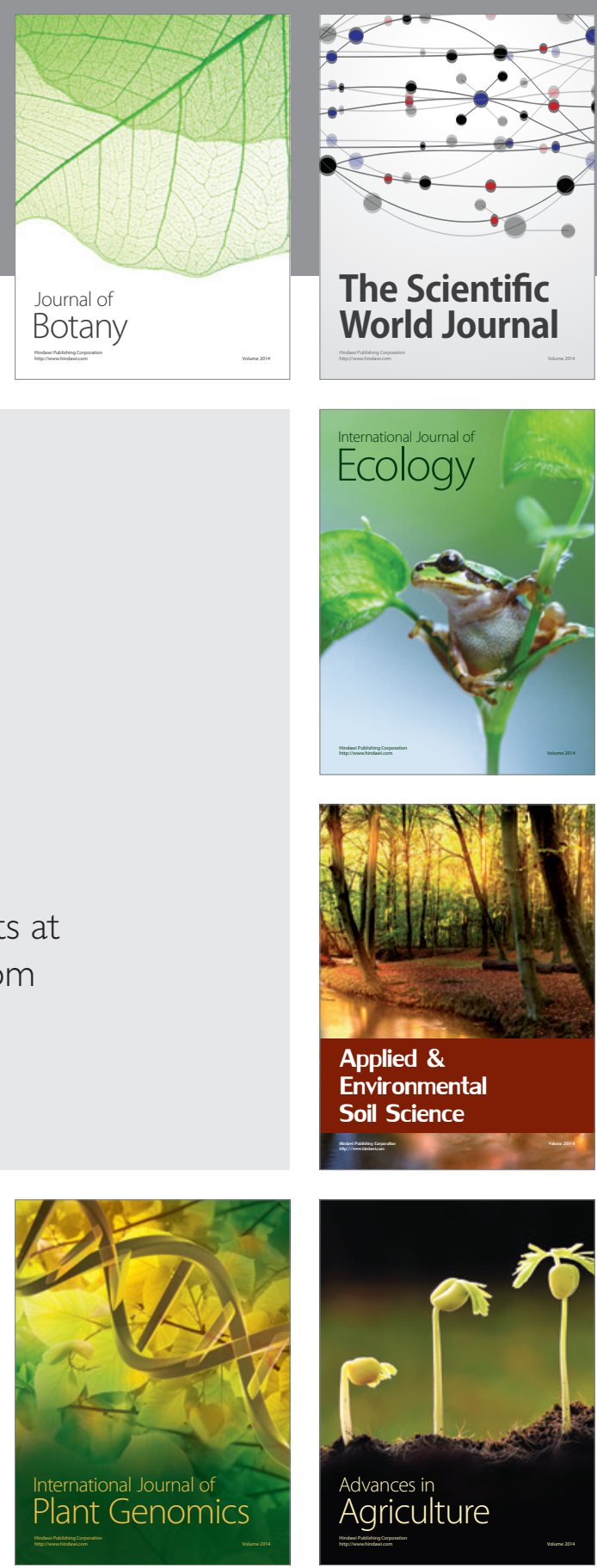

The Scientific World Journal
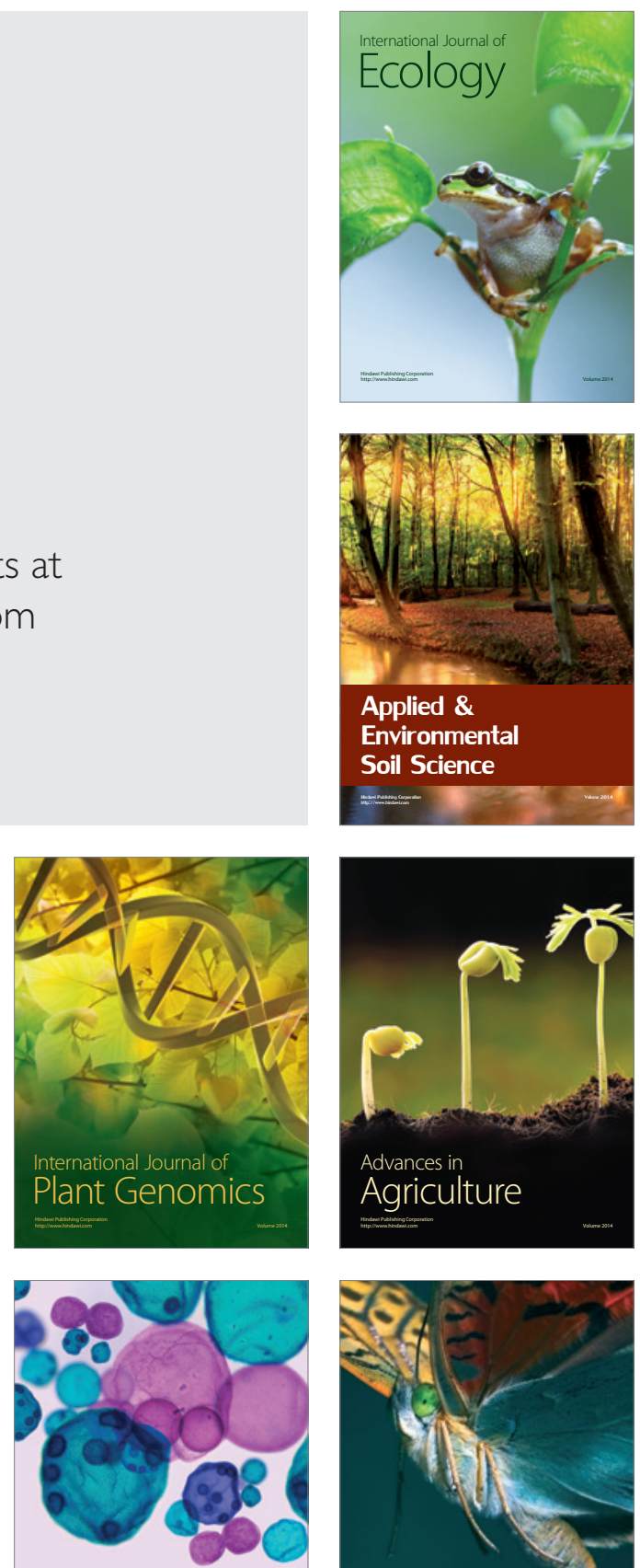

International Journal of Microbiology

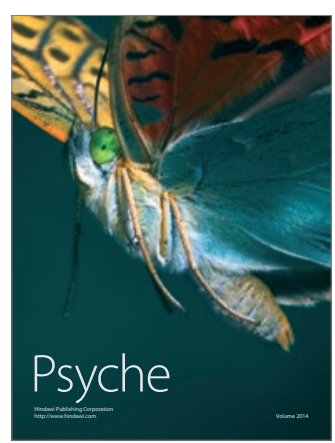

